\title{
EL VOLUNTARIADO COMO MANIFESTACIÓN DE LA RESPONSABILIDAD SOCIAL DEL ALUMNO DE CIENCIAS ECONÓMICAS
}

GASTÓN MAXIMILIANO CABRAL $2^{\text {do }}$. PREMIO - ESTUDIANTE CONCURSO $60^{\circ}$ ANIVERSARIO

FACULTAD DE CIENCIAS ECONÓMICAS - UNNE 


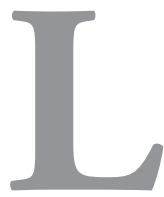

os estudiantes de la Facultad de Ciencias Económicas de la UNNE somos instruidos con conocimientos científicos y técnicos, para desempeñar de una manera arreglada, una profesión independiente.

Pero no solo somos personas a las cuales, la Facultad intenta introducir un cumulo de conocimientos, sino que en nuestra formación se incluyen aspectos éticos y culturales, propios de quienes ostentan un título de grado.

Es por esto que debemos estar conscientes de la responsabilidad que tenemos por estar dentro de una institución. Y como estudiantes de la Facultad, también somos una de sus caras visibles, por lo que debemos enmarcar nuestras acciones a esta última.

Refiriéndonos específicamente a la "Responsabilidad Social”, debemos destacar que esta última, integra nuestra formación y sigue los lineamientos de nuestra cultura académica.

En otras palabras, La 'Responsabilidad Social” está en nuestra esencia. Tal como lo establece el Artículo $2^{\circ}$ del Estatuto de la UNNE: ' La Universidad Nacional del Nordeste (...) No se desentiende de los problemas sociales, políticos e ideológicos, sino que debe estudiarlos científicamente. Procura formar integral e interdisciplinariamente a sus componentes e infundir en ellos el espíritu crítico y a la vez el sentido de responsabilidad personal y social (...)' '.

De aquí se desprende que este tema no nos debe ser indiferente, y es hora que los alumnos tomemos un cabal conocimiento de nuestros derechos, obligaciones, orígenes y responsabilidades; para empezar desde ahora a forjar una imagen de seres loables y decorosos; y tomemos todas las herramientas necesarias para seguir sosteniéndola, a lo largo de todo el ejercicio de nuestra profesión.

Una de las formas de exteriorizar esa 'Responsabilidad Social”, es a través del Voluntariado Universitario. Un término que se puso muy de moda en este último tiempo y el cual está tomando cada vez más entidad a través de la articulación entre las Universidades Nacionales y el Ministerio de Educación de la Nación.

Pero ¿Qué entendemos por Voluntariado Universitario? Mucho se habla del trabajo comunitario, caritativo y solidario en los Medios Masivos de Comunicación (MMC). Haciendo documentales en África, viendo a celebridades promocionando campañas solidarias, y hasta escuchamos mucho hablar sobre distintas organizaciones. Pero ¿Realmente decodificamos el mensaje? ¿Realmente logramos precisar la trascendencia de cada concepto?

Ateniéndonos a nuestro tema, el Voluntariado es el trabajo realizado sin fines de lucro y en aras de ayudar y contribuir al medio y/o comunidad a la cual uno pertenece.

Pero cuando hablamos de ser voluntario, muchas veces podemos llegar a imaginar que vamos a ir a trabajar gratuitamente para otras personas, y siguiendo fielmente nuestra formación, resaltamos el aspecto monetario de la relación.

Pero ser voluntario no significa hacer el trabajo de otra persona de manera solamente gratuita. El voluntariado Universitario no sustituye, ni desplaza a los trabajadores remunerados. Porque el voluntariado persigue otros fines y tiene lugar en otros ámbitos. 
Asimismo el beneficio del voluntariado no se reduce a una persona o a un grupo de personas determinadas. Sino que los destinatarios, son todos los integrantes de una comunidad, y los beneficios se suman al bien común de esta. Por lo que de manera indirecta, los resultados vuelven a los voluntarios por formar parte de la sociedad en primer lugar.

Por otro lado ¿Qué nos motivaría a participar de los proyectos del voluntariado? Algunas de las razones podrían ser: Intentar mejorar la sociedad a la cual pertenecemos, aportando los conocimientos y cualidades que nos son propias de los alumnos de ciencias económicas, para dar respuesta a las distintas problemáticas que se presentan en el contexto, complementando la actividad del Estado.

Otra razón podría ser satisfacer la necesidad de explotar la solidaridad que los seres humanos tenemos dentro, buscando un bienestar espiritual y moral.

Quizás podríamos necesitar algún medio para transformar nuestros sentimientos agridulces, en energía positiva y enfocarla en una buena causa. Buscando un cable a tierra en una actividad tan pura como en la que consiste ayudar.

O algunos podríamos hasta sentirnos en deuda con la sociedad, por lo que esta nos ha dado, a lo que buscaríamos la forma de compensar esa acreencia, mediante la realización de un trabajo desinteresado.

Como lo venimos resaltando, si bien el voluntariado no persigue fines materiales, es indudable que este tipo de labor trae aparejados galardones inmateriales, muchas veces pasados por alto.

Estas recompensas, entre otras, podrían consistir en: Sentirse incluido en un Proyecto Social; integrándolo, llevándolo a cabo. No hay nada más satisfactorio para un ser humano que sentirse contenido y tenido en cuenta.

Desarrollar una habilidad empática que permita entender el mundo externo que nos rodea, logrando un conocimiento introspectivo de cada uno, que resalten los signos de humanidad y favorezca la maduración personal y profesional. Entender mejor la realidad que nos toca vivir, apreciándola desde otro punto de vista y compartiéndola con similares. Y Crear relaciones sociales que posibilitarían en un futuro lograr una mejor desenvolvimiento en la comunidad. Lo que nos permitiría manejarnos de una manera más eficaz para lograr nuestros objetivos. Quizás podamos insertarnos laboralmente, afiancemos lazos fraternales, conozcamos pares, etc.

Más arriba mencionamos que el Ministerio de Educación de la Nación, entre otros organismos, articula mecanismos para concretar actos del Voluntariado Universitario mediante distintas convocatorias que realiza, buscando la presentación de proyectos con distintas temáticas; ofreciendo un menú variado para lograr incumbir a todos los miembros de la Educación Superior Universitaria.

Estos proyectos pueden relacionarse con la difusión de la cultura y el arte, el cuidado del medioambiente, la promoción de la lectura, el apoyo educativo, entre otros.

No hay que perder de vista, que el Voluntariado Universitario se traduce en proyectos, y que luego, estos son sometidos a una evaluación de factibilidad, por lo que no tenemos que 
desalentarnos si por ahí, un proyecto del cual formamos parte, no reúne todas las condiciones de viabilidad, o, no es aprobado por alguna razón objetiva. Tenemos que perseverar y no dejar ante el primer obstáculo que se nos pueda presentar.

De esta manera podemos concluir diciendo que el alumno de Ciencias Económicas, es un sujeto con características distintivas que está en condiciones de proporcionar elementos sustanciales, y trabajar en conjunto con los demás actores de la UNNE, para la resolución de los problemas y necesidades de nuestra región a través de la realización de proyectos de Voluntariado Universitario que manifiesta la 'Responsabilidad Social”.

\section{REFERENCIAS BIBLIOGRAFICAS}

- wikipedia.com

- www.me.gov.ar

- www.unne.edu.ar

\section{CURRÍCULUM VITAE}

GASTÓN MAXIMILIANO CABRAL.

Contador Público - UNNE (Julio 2011).

Mandatario Nacional del Automotor y Créditos prendarios (d. Diciembre 2009).

Miembro Activo de la Comisión de Jóvenes Profesionales, del Consejo Profesional de Ciencias Económicas de la Provincia del Chaco (d. Febrero 2012).

cabralgaston@yahoo.com.ar 